\title{
Digitalization in Realization of Ecological and Economic Principles of Managing Sustainable Development of Agrarian Enterprises
}

\author{
Mykola V. Zos-KIOR ${ }^{i}$, VALeriI Y. Ilinii, IrYNa M. KYryLIUK ${ }^{i i i}$, \\ OLEKSANDR V. SOLOD ${ }^{i v}$
}

\begin{abstract}
The article describes the digitalization of ecological and economic principles of agricultural enterprise development management. It presents effective techniques for adapting enterprises to the challenges of the smart economy, which changes human needs, products, services, value chains, markets, processes, business models, forms of competition and business partnerships. The article proves the efficiency of precision farming, which includes parallel driving, yield mapping, differentiated application of seeds and fertilizers. It is determined that the lack of systemic demand for digital solutions from domestic agricultural enterprises and rural communities and unpreparedness (strategic, financial, technological, personnel, organizational, etc.) of most enterprises and communities to cardinal innovations significantly deter the formation of smart agribusiness in Ukraine. The article describes the system of measured indicators and capabilities of the Hummingbird Technologies platform and consequences of its implementation for land management, in particular normalized relative biomass index, leaf surface index, crop heterogeneity map, plant lodging risk map, weed map, seedling density map, electronic maps creation tasks, task map for differentiated desiccation, task map for differentiated application of herbicides, task map for differentiated application of growth regulators in plants. It justifies the need to intensify the work of rural a community, which try to communicate with agricultural producers on mutually beneficial terms and with other stakeholders for the sustainable development of rural areas. The issues of participation of rural communities in projects to increase soil fertility, organization of organic farms, service cooperatives, which are directly or indirectly related to the effective management of environmental and economic development of agricultural enterprises. The article shows the necessity of professional development of business engineers, personnel and strengthening of role of analytics for agricultural enterprises to digitalize the economic activity.
\end{abstract}

Keywords: agrarian enterprises, development, digitalization, ecological and economic principles, management.

Abbreviations:

IT - information technology;

ESA - European Space Agency.

УДК 332.33:332.2.021.8

JEL Codes: O13, O33, Q20

Introduction. Today, land resource management in Ukraine is facing the need for adaptation to smart economy. It is based on the introduction of new technologies, which are

\footnotetext{
${ }^{i}$ Mykola V. Zos-Kior, Dr. (Economics), Associate Professor, Professor of the Department of Management, Poltava State Agrarian Academy;

${ }^{i i}$ Valerii Y. Ilin, Dr. (Economics), Professor, Professor of the Department of Accounting and Control in Branches of the Agroindustrial Sector, Kyiv National Economic University named after Vadym Hetman;

iii Iryna M. Kyryliuk, C.Sc. (Economics), Associate Professor of the Management and Economic Security Department, Bohdan Khmelnytsky National University of Cherkasy;

${ }^{i v}$ Oleksandr V Solod, Postgraduate student of the Management Department, Poltava State Agrarian Academy, Ukraine, Poltava.
}

(C) M. V. Zos-Kior, V. Y. Ilin, I. M. Kyryliuk, O. V. Solod, 2020.

https://doi.org/10.21272/mer.2020.88.02

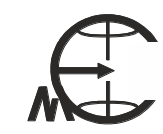

Mechanism of Economic Regulation, 2020, No 2 
М. В. Зось-Кіор, В. Ю. Ільӥн, І. М. Кирилюк, О. В. Солод. Діджиталізація в реалізації

often known as Industry 4.0, or the fourth industrial revolution. Experts of the international company Boston Consulting Group Big prove that data and analytics, The Industrial Internet of Things, Autonomous robots, Augmented reality, The cloud, Additive manufacturing, Horizontal and vertical system integration, Cybersecurity, Simulationthe have great influence on the development of the conditions, models and the effeciency of innovative agrarian business. Smart technologies are radically changing human needs, products, services, value chains, markets, technological processes, business models, forms of competition and business partnerships. The advancement of the ideas of digitization of production and Industry 4.0 in the Ukrainian agricultural sector is very slow, mainly through initiatives and projects of business communities in the field of automation of agrarian production.

Problem statement. The issue of digitalization of ecological and economic principles of agricultural enterprise development management attracts the attaention of different scientists. V. M. Andrushchenko, V. F. Stukach, O. V. Chaplygin, O. V. Shubravskaya, C. Koeber [1-5] tackle the issues of ecological and economic development.

However, digitalization issues, intensification of rural communities, especially their participation in projects related to the effective management of environmental and economic development of agricultural enterprises are not sufficiently considered.

The purpose of the article is to study the process of digitalization of ecological and economic principles of agricultural enterprise development management.

Results of the research. The tasks that are solved today in agriculture by means of IT can be divided into general and specific, inherent only to the agricultural sector.

Precision farming - is a set of actions that maximize fieldwork efficiency. It includes parallel driving, automatic shutdown of units on the floors, differentiated seed and fertilizer application, yield mapping.

a) Parallel driving allows technological operations at any time of day, minimizes overlaps and gaps during plowing of fields, introduction of seeds, fertilizers, plant protection products, and automatically process data on completed operations. Course indicators or autopilots, and comprehensive training of machine operators, engineers and agronomists may help. As a result, the costs are reduced and the deadlines are shortened.

b) Fuel or grain expense sensors.

c) Monitoring of seed sowing and system of section cut-offs at places where seed application overlaps come out. The calculation of overlaps is done by processing the data of GPS-sensors installed on agricultural machinery.

Crop condition monitoring - using of drones and satellites allows remote control of crops growth and recognition of diseases and pests on time.

Information services. For example, the information system may provide information about the value of crops in the internal and external markets, about episodic situation, about legislative innovations. Large Ukrainian agricultural enterprises use different types of technologies, and also cooperate with IT companies to develop their own IT products [2].

The most popular technologies in Ukraine its tracking of equipment and control of the use of fuel and other consumables, the system of parallel driving, satellite monitoring of fields and other methods of aerial photography, technologies of watering control, auto piloting and differentiated introduction for agricultural machinery. To introducing innovations, in agrarian company must be created for this condition: they need purchased the necessary equipment, prepared an experienced team, created the necessary infrastructure, and achieved certain stages of development and size of business. Before implementing agribusiness information systems, it is necessary to clearly to line up the business process, taking into account the structure of 
Mykola V. Zos-Kior, Valerii Y. Ilin, Iryna M. Kyryliuk, Oleksandr V. Solod. Digitalization in Realization of Ecological and Economic Principles of Managing Sustainable Development of Agrarian Enterprises

company management, the possibilities of technologies, the competence of employees. Sometimes it takes many months to sort out business processes before implementing a solution. Without such prior system work, implemented IT solutions are inefficient. As a result, without receiving the expected result, farmers abandon other elements of technology and continue to operate as before. Therefore, enhancing the technological competence of future users, conducting preliminary training and demonstrating the capabilities of the new system will help them overcome stress and facilitate the spread of innovations.

The catalyst for the development of information technology in agriculture can be the use of opportunities in the consulting market. Consulting companies research the innovation market for agribusiness, create and maintain relationships with IT companies and startups, create a registry of technologies aimed at increasing the profitability of agribusiness, and provide assistance in finding business partners. In addition, consulting companies provide comprehensive analytics valuable for making optimal decisions in the face of high risks of constant price changes for mineral fertilizers, seeds, plant protection products, fuel and lubricants, crop production, helps to minimize the likelihood of management and technological errors of agribusinesses.

At the same time, a significant deterrent to the incipience of smart agribusiness in Ukraine is the lack of systematic demand for digital solutions from domestic agricultural enterprises and rural communities. In a broad sense, this means that most businesses and communities are unprepared (strategic, financial, technological, personnel, organizational, etc.) for radical innovations. Therefore, the analysis of microeconomic problems of becoming a smart economy should begin with an analysis of the general context of development of innovation activity of enterprises and communities. However, the cardinal changes in the external environment related to global processes of digitalization, the development of cyber-physical systems and the incipience of Industry 4.0 require new approaches to managing the innovation activities of domestic agricultural enterprises and communities.

Factors such as the lack of funds within the enterprise and the community, credit or private capital, high costs of innovation, difficulties in obtaining state pre-aid, and regulations that have created an additional burden are most hindered by the introduction of innovation. Much less attention is paid by businesses and communities to the lack of skilled professionals, collaborative partners and the uncertain demand for innovative ideas. As the processes of digital transformation in the domestic agribusiness today are still have "point" nature, their main directions and factors of success should be explored by concrete examples.

For example, Ukrlandfarming group employs a TETRA system to monitoring the execution of technology operations, which generates operational reporting and allows decisions to be made about moving and improving the use of machinery and vehicles.

"Kernel” Agro Holding introduces Digital Agro Business complex - a management system that maximizes profit and yield on a single field.

Ukrainian producer and exporter of agricultural crops "Agroproperis" operates its own software product "APAgronomist", thanks to which each agronomist has information about the residues of materials, moves them and controls the write-off, records the performed technological operations, the number of fertilizers and plants protecting toolses made, can get data about the mechanics who worked on the specific area. The program helps to plan the field work, it itself determines the list of necessary operations, as well as equipment and units, taking into account their availability on this day. Other market participants also use software to monitor equipment, automate data collecting, and operational accounting of agricultural work performed. 
М. В. Зось-Кіор, В. Ю. Ільїн, І. М. Кирилюк, О. В. Солод. Діджиталізація в реалізації

The "Mironovsky Hleboprodukt" company has a separate department responsible for innovation implementation, and "Astarta" holding develops a separate Agro Core company, created in partnership with Borsch Ventures.

These agro holdings, due to their extremely high level of innovation financing, achieve effective management of land resources and agribusiness as a whole. At the same time, a number of objectives of constant development rural areas are also to some extent achieved.

It should also be noted that the effectiveness of the management of land resources today is due to the use of certain platforms that allow the monitoring of the condition and development of basic crops throughout the growing season. For example, the Hummingbird Technologies platform, in addition to directly monitoring, allows creating the task cards for the differential application of fertilizers and plant protection products. The platform allows regular monitoring using satellite imagery, and the images, collected using small aircraft and unmanned aerial vehicleses are processed by automatically stapling into orthophoto plans. Using machine learning and artificial intelligence algorithms, Hummingbird Technologies generates plant-state analytics in just 24 hours from the time the platform uploads the images.

In 2018, Hummingbird Technologies was able to raise 4.1 million \$ investment, becoming the first AgTech company invested by the European Space Agency. Starting in 2019, the digital solution from Hummingbird Technologies begins to work in the Ukrainian market immediately with a large project about digitize the monitoring of the 200 thousand hectares of agricultural holding farms of Continental Farmers Group. Unmanned aerial vehicleses and small aircraft, equipped with multispectral or conventional RGB cameras, carry out the required number of flights at different stages of plant development. The terms are different for each culture which is monitoring. They are determined by the particularities of development. Filming is carried out from an altitude of 90-220 m. The pictures are uploaded to the platform where their processing and analysis is carried out (Table 1).

Rural communities are also quite active in the effective management of land resources and are trying to communicate with agri-producers in every way on mutually beneficial terms and with other stakeholders in order to ensure sustainable development of rural areas, including the implementation of soil fertility projects and organization of organic farms which serving cooperatives, directly or indirectly related with the effective management of land resources. Here are some specific examples in the Poltava region.

The first and largest organic raspberry farm in Ukraine is "Dykansky yoghody" (village Balasne of Dykansky district of Poltava region) was created in 2016 as an agricultural service cooperative. This was made possible by the regional program of development and support of the agrarian complex of Poltava region. Undoubtedly, the initiative of local farmers aimed at developing organic farming in the region played a major role. Currently, 13 hectares of land are laid under raspberries, about 150 jobs are provided, and certified organic products are sold both in Ukraine and in EU countries. In the short term, the development of the cooperative is planned to expand the plantation area and not only grow berries, but also their further processing - the production of jams.

Another noteworthy example is the Sergiy United Community of Poltava region, which also invests in future entrepreneurs and co-operatives. Thanks to the District Entrepreneurship Support Fund, any resident can get a 300.000 UAH interest free loan on the security of production property purchased for these funds. Under such favorable conditions for opening a business, community have a bakery and dairy already appeared in the community, a cooperative "Sergiyevsky Berry" specializing on organic berry was created. Recently, 15 hectares of land was allocated directly to the community for cultivation of demanded produce. This decision was 
Mykola V. Zos-Kior, Valerii Y. Ilin, Iryna M. Kyryliuk,

Oleksandr V. Solod. Digitalization in Realization of Ecological and Economic Principles of Managing Sustainable Development of Agrarian Enterprises

made in favor of organic farming instead of letting the land to agricultural holdings for corn and sunflower-depleted soils. Local residents began not only to realize the cultivated, but also to form the added value - to dry fruits and berries, to produce dried jam, to prepare medicinal herbs, to make borscht set, to develop eco-tourism.

Table 1

Measured indicators and capabilities of the Hummingbird Technologies platform and implications of his implementation for managing land resources

\begin{tabular}{|c|c|}
\hline Indicator & Implications for land management \\
\hline $\begin{array}{l}\text { Normalized Relative } \\
\text { Biomass Index }\end{array}$ & $\begin{array}{l}\text { Correctly interpreting the obtained data with given to the vegetation and crop } \\
\text { stage, we can identify problem areas - weediness, evaluate the quality of } \\
\text { field work, determine the order of harvest in the fields, etc. }\end{array}$ \\
\hline $\begin{array}{l}\text { The map of the } \\
\text { heterogeneity of crops }\end{array}$ & $\begin{array}{l}\text { Field studies of problem areas are needed to determine the causes of slow } \\
\text { development. Timely reaction will help increase the potential for field yield }\end{array}$ \\
\hline $\begin{array}{l}\text { Map of risk of lodging } \\
\text { of plants }\end{array}$ & $\begin{array}{l}\text { The information is used to investigate the agronomist of areas with high risk } \\
\text { of plant lodging and to make decisions for further care of crops or the use of } \\
\text { protection technology: determination of doses of growth regulators, creation } \\
\text { of a map-task for differentiated introduction. }\end{array}$ \\
\hline Couch grass map & $\begin{array}{l}\text { The maps show the locations of weed concentration, after further } \\
\text { identification of the species composition and the choice of protection } \\
\text { technology, it is possible to create task cards for differential or point spraying }\end{array}$ \\
\hline Ladder density map & $\begin{array}{l}\text { Allows you to evaluate the performance of sowing equipment, determine the } \\
\text { quality of sowing, methods of care, the expediency of recharge or replanting }\end{array}$ \\
\hline $\begin{array}{l}\text { Creating electronic } \\
\text { task-maps }\end{array}$ & $\begin{array}{l}\text { Thanks to a differentiated approach to the determination of dosages based } \\
\text { on the data of vegetation indices, yields are increased without increasing the } \\
\text { amount of nitrogen introduced }\end{array}$ \\
\hline $\begin{array}{l}\text { Task-map on differen- } \\
\text { tiating desiccation }\end{array}$ & $\begin{array}{l}\text { After determining the areas of uneven ripening, a map is formed for the } \\
\text { differential application of desiccant }\end{array}$ \\
\hline $\begin{array}{l}\text { Task-map for } \\
\text { differentiated herbicide } \\
\text { application }\end{array}$ & $\begin{array}{l}\text { In addition to significant savings of drugs and reduced costs of water } \\
\text { delivery for spraying, stress is reduced for cultural plants, which allowing } \\
\text { increasing of yields }\end{array}$ \\
\hline $\begin{array}{l}\text { Task-map for } \\
\text { differentiation of plant } \\
\text { growth regulators }\end{array}$ & $\begin{array}{l}\text { In addition to saving on the cost of expensive drugs and reducing the cost of } \\
\text { delivering water for spraying, it also balances the vegetative development of } \\
\text { plants on the field, at the same time reducing stress for cultural plants, which } \\
\text { together allows for increased yields. }\end{array}$ \\
\hline
\end{tabular}

Soil fertility increase is also overtaking in Kolomata United Community of Poltava region. Innovations have been introduced in the fight against ragweed. Instead of mowing weeds or treating them with herbicides, as most farmers do, they use a mineral in the community, which is a natural salt-bischofite. Its advantages are that it is extracted in Poltava region and when fighting with ragweed, in comparison with other analogues, does not harm the environment at all. Scientists have already confirmed the effectiveness of this method. Bischofite suppresses only dicotyledonous plants, which include ragweed, but is safe for cereals, so they can cultivate fields without harm to wheat, barley, corn, etc. The effect of mineral processing is 3-4 years, it does not affect the soil in any way, and it can be used even as a fertilizer. In addition, according to the inventors, bischofite also sterilizes ragweed pollen, eliminating toxins after treatment, and thus eliminating the risk of allergy sufferers. Thus, given the relevance and effectiveness of this method initiated by community, it is planned to be further disseminated within the area. 
М. В. Зось-Кіор, В. Ю. Ільӥн, І. М. Кирилюк, О. В. Солод. Діджиталізація в реалізації еколого-економічних принципів управління сталим розвитком аграрних підприємств

Conclusions and prospects of further research. Summarizing all of the above, we can say that the examples, as well as a number of other projects implemented in the area, demonstrate the interest of both farmers, residents of Poltava Region, and investors for a radical change in the views on agricultural resources management and implementing sustainable development goals. Cooperation helps companies to be efficient. Companies also need expressive leadership, dedicated managers, setting goals, and supporting subordinates. At the same time, it is necessary to train business engineers and operating staff to think about business, that is, to translate projects that need to be completed into business metrics that show the added value created by this initiative for the company.

\section{References}

1. Andrushchenko, V. M. (2015). Svitovyi dosvid perekhodu vid tradytsiinoho do orhanichnoho ahrovyrobnytstva ta mozhlyvosti yoho zastosuvannia v Ukraini [World experience of transition from traditional to organic agro-production and the possibility of its application in Ukraine]. Ahrosvit, 7 , 55-61.

2. Stukach, V.F. (2013). Mekhanizmy motivatsii sobstvennikov zemli v sfere primeneniya pochvozashchitnykh tekhnologiy [Mechanisms of motivation of landowners in the field of application of soil protection technologies]. Biznes. Obrazovanie. Pravo. Vestnik Volgogradskogo instituta biznesa, 3 (24), 106-114.

3. Chaplyhin, O. V. (2012). Ekolohichni investytsii v protsesi ekolohizatsii ekonomiky [Environmental investments in the process of greening the economy]. Visnyk Zaporizkoho natsionalnoho universytetu, 3 (15), 154-158.

4. Shubravska, O. V. (2014). Ahroprodovolchyi rozvytok Ukrainy v konteksti hlobalnykh vyklykiv [Agri-food development of Ukraine in the context of global challenges]. Ekonomika APK, 7, 52-58.

5. Koeber, C. (2011). Consumptive labor: the increasing importance of consumers in the labor process. Humanity \& Society. Vol 35, № 3. 205-232.

Manuscript received 12 May 2020

Диджитализация в реализации эколого-экономических принципов управления устойчивым развитием аграрных предприятий

\section{НИКОЛАЙ ВАЛЕРИЕВИЧ ЗОСЬ-КИОР*, ВАЛЕРИЙ ЮРИЕВИЧ ИЛЬИН*, ИРИНА НИКОЛАЕВНА КИРИЛЮК ${ }^{* * *}$, АЛЕКСАндр ВАДимович Солод ${ }^{* * *}$}

* доктор экономических наук, доцент, профессор кафедры менеджмента, Полтавская государственная аграрная академия, ул. Сковороды, 1/3, г. Полтава, 36003, Украина, тел.: 00-380-50-1325043, e-mail: zoskior@gmail.com

** доктор экономических наук, профессор, профессор кафедры учета, контроля и налогообложения агробизнеса, Киевский национальный экономический университет им. Вадима Гетьмана,

nросп. Победы, 54/1, г. Киев, 03057, Украина, тел.: 00-380-50-1568259, e-mail:villin2015@gmail.com

*** кандидат экономических наук, доцент кафедры менеджмента и экономической безопасности, Черкасский национальный университет имени Богдана Хмельницкого,

б-р Шевченка, 81, м. Черкаси, 18031, Україна, тел.:00-380-98-4517881,e-mail: in_kirilyk@ukr.net 
Mykola V. Zos-Kior, Valerii Y. Ilin, Iryna M. Kyryliuk,

Oleksandr V. Solod. Digitalization in Realization of Ecological and Economic Principles of Managing Sustainable Development of Agrarian Enterprises

***** аспирант кафедры менеджмента Полтавской государственной аграрной академии,

ул. Сковороды, 1/3, г. Полтава, 36003, Украина,

тел.: 00-380-99-2520366, e-mail: vladiksevryukov@gmail.com

Рассмотрены вопросы диджитализации эколого-экономических принципов управления развитием аграрного предприятия. Представлены эффективные техники адаптации предприятий к вызовам смарт-экономики, которая меняет человеческие потребности, продукты, услуги, цепочки ценности, рынки, технологические процессы, бизнес-модели, формы конкуренции и делового партнерства. Доказана эффективность точного земледелия, включая параллельное вождение, картирование урожайности, дифференцированное внесение семян и удобрений. Определено, что весомым сдерживающим фактором становления в Украине смарт-агробизнеса является отсутствие системного спроса на цифровые решения со стороны отечественных аграрных предприятий и сельских общин и неготовность (стратегическая, финансовая, технологическая, кадровая, организационная и т. д.) большинства предприятий и общин в кардинальных инновациях. Рассмотрена система измеряемых показателей и возможности платформы Hummingbird Technologies и последствия ее внедрения для управления земельными ресурсами, в частности нормализованный относительный индекс биомассы, индекс листовой поверхности, карта неоднородности посевов, карта риска полегания растений, карта наличии сорняков, карта густоты всходов, создание электронных карт задач, карта-задание на дифференцированное проведение десикации, карта-задание на дифференцированное внесение гербицидов, карта-задание на дифференцированное внесение регуляторов рост у растений. Доказана необходимость активизации работы сельских общин, которые пытаются всячески коммуницировать с агропроизводителями на взаимовыгодных условиях и с другими стейкхолдерами для устойчивого развития сельских территорий. Рассмотрены вопросы участия сельских общин в проектах по повышению плодородия почв, организации органических хозяйств, обслуживающих кооперативов, прямо или косвенно связанные с эффективным управлением эколого-экономическим развитием аграрных предприятий. Доказана необходимость повышения квалификации бизнес-инженеров и персонала и усиление аналитического инструментария аграрных предприятий при внедрении средств диджитализации хозяйственной деятельности.

Ключевые слова: аграрные предприятия, диджитализация, развитие, управление, экологоэкономические принципы.

$$
\begin{gathered}
\text { Mechanism of Economic Regulation, 2020, No 2, 29-36 } \\
\text { ISSN 1726-8699 (print) }
\end{gathered}
$$

Діджиталізація в реалізації еколого-економічних принципів управління сталим розвитком аграрних підприсмств

\section{МИКОЛА ВАЛЕРІйОВИЧ ЗОсь-КІоР*, ВАЛЕРІй ЮРІйОВИЧ ІЛЬЇн ${ }^{* *}$, ІрИНА МИКОЛАЇвНА КИРИЛЮК ${ }^{* * *}$, ОЛЕКСАНДР ВАДИМОВИч СоЛОД ${ }^{* * * *}$}

* доктор економічних наук, доцент, професор кафедри менеджменту,

Полтавська державна аграрна академія,

вул. Сковороди, 1/3, м. Полтава, 36003, Україна,

тел.: 00-380-50-1325043, e-mail: zoskior@gmail.com

** доктор економічних наук, професор, професор кафедри обліку, контролю та оподаткування агробізнесу, Київський національний економічний університет ім. Вадима Гетьмана, просп. Перемоги, 54/1, м. Київ, 03057, Україна, тел.:00-380-50-1568259, e-mail:villin2015@gmail.com 
М. В. Зось-Кіор, В. Ю. Ільӥн, І. М. Кирилюк, О. В. Солод. Діджиталізація в реалізації еколого-економічних принципів управління сталим розвитком аграрних підприємств

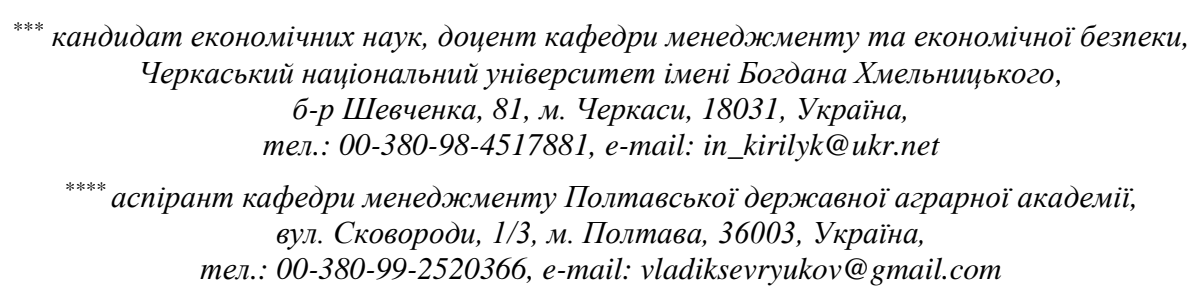

Розглянуто питання діджиталізації еколого-економічних принципів управління розвитком аграрного підприємства. Представлено ефективні техніки адаптації підприємств до викликів смартекономіки, що змінює людські потреби, продукти, послуги, ланцюжки вартості, ринки, технологічні процеси, бізнес-моделі, форми конкуренції та ділового партнерства. Доведено ефективність точного землеробства, що включає паралельне водіння, картування врожайності, диференційоване внесення насіння та добрив. Визначено, що вагомим стримуючим чинником становлення в Україні смарт-агробізнесу $є$ відсутність системного попиту на цифрові рішення 3 боку вітчизняних аграрних підприємств та сільських громад та неготовність (стратегічну, фінансову, технологічну, кадрову, організаційну і т. ін.) більшості підприємств та громад до кардинальних інновацій. Розглянута система вимірюваних показників і можливості платформи Hummingbird Technologies та наслідки її впровадження для управління земельними ресурсами, зокрема нормалізований відносний індекс біомаси, індекс листкової поверхні, карта неоднорідності посівів, карта ризику вилягання рослин, карта наявності бур'янів, карта густоти сходів, створення електронних карт завдань, карта-завдання на диференційоване проведення десикації, картазавдання на диференційоване внесення гербіцидів, карта-завдання на диференційоване внесення регуляторів росту рослин. Доведено необхідність активізації роботи сільських громад, які намагаються всіляко комунікувати 3 агровиробниками на взаємовигідних умовах та 3 іншими стейкхолдерами задля сталого розвитку сільських територій. Розглянуто питання участі сільських громад у проєктах щодо підвищення родючості грунтів, організації органічних господарств, обслуговуючих кооперативів, що прямо чи опосередковано пов'язані з ефективним управлінням еколого-економічним розвитком аграрних підприємств. Доведено необхідність підвищення кваліфікації бізнес-інженерів і персоналу та посилення аналітичного інструментарію аграрних підприємств при впровадженні засобів діджиталізації господарської діяльності.

Ключові слова: аграрні підприємства, діджиталізація, екологічні та економічні засади, розвиток, управління.

JEL Codes: O13, O33, Q20

Table: 1 ; References: 5

Language of the article: English

Лimepamypa

1. Андрущенко, В. М. Світовий досвід переходу від традиційного до органічного агровиробництва та можливості його застосування в Україні / В. М. Андрущенко // Агросвіт. - № 7. - 2015. - С. 55-61.

2. Стукач, В.Ф. Механизмы мотивации собственников земли в сфере применения почвозащитных технологий / В. Ф. Стукач // Бизнес. Образование. Право. Вестник Волгоградского института бизнеса. - 2013. - № 3 (24). - С. 106-114.

3. Чаплигін, О. В. Екологічні інвестиції в процесі екологізації економіки / О. В. Чаплигін // Вісник Запорізького національного університету. - 2012. - № 3 (15). - С. 154-158.

4. Шубравська, О.В. Агропродовольчий розвиток України в контексті глобальних викликів / О. В. Шубравська // Економіка АПК. - 2014. - № 7. - С. 52-58.

5. Koeber, C. Consumptive labor: the increasing importance of consumers in the labor process / C. Koeber // Humanity \& Society. - 2011. - Vol 35, № 3. - P. 205-232. 